\title{
Effects of DNMT1 silencing on malignant phenotype and methylated gene expression in cervical cancer cells
}

Yi Zhang ${ }^{1,2 \dagger}$, Fu-qiang Chen ${ }^{1 \dagger}$, Ye-hong Sun ${ }^{1 \dagger}$, Shu-yan Zhou ${ }^{1 \dagger}$, Ti-yuan $\mathrm{Li}^{1 *}$ and Rui Chen ${ }^{1,2+}$

\begin{abstract}
Background: DNA methylation has been widely used in classification, early diagnosis, therapy and prediction of metastasis as well as recurrence of cervical cancer. DNMT methyltransferase 1 (DNMT1), which plays a significant role in maintaining DNA methylation status and regulating the expression of tumor suppressor genes. The aim of this research was to investigate the relationship between DNMT1 and abnormal methylation of tumor suppressor genes and malignant phenotype in cervical cancer.

Methods: Levels of DNMT1 mRNA and protein were detected using QPCR and Western blot, respectively. Cell proliferation was analyzed by MTT and apoptosis was performed by Annexin V-FITC/PI double staining flow cytometry, respectively. MeDIP-qPCR and APCR were performed to measure demethylation status and mRNA reexpression level of 7 tumor-suppressor genes (CCNA1, CHFR, FHIT, PAX1, PTEN, SFRP4, TSLC1) in Hela and Siha cells after silencing DNMT1.

Results: The average expression levels of DNMT1 mRNA and protein in Hela and Siha cells were decreased significantly compared with control group. The flow cytometry and MTT results showed that Hela and Siha cells apoptosis rates and cell viabilities were $19.4 \pm 2.90 \%, 25.7 \pm 3.92 \%$ as well as $86.7 \pm 3.12 \%, 84.16 \pm 2.67 \%$ respectively $48 \mathrm{~h}$ after transfection $(P<0.01)$. Furthermore, the promoter methylation of five tumor suppressor genes was decreased with the increased mRNA expression after silencing DNMT1, whereas there were no significant changes in PTEN and FHIT genes in Hela cells, and CHFR and FHIT genes in Siha cells.
\end{abstract}

Conclusions: Our experimental results demonstrate that methylation status of DNMT1 can influence several important tumor suppressor genes activity in cervical tumorigenesis and may have the potential to become an effective target for treatment of cervical cancer.

\section{Background}

Cervical cancer is the second most common cancer in women worldwide and the leading cause of cancer deaths in women in developing countries. It is obviously that many genetic and epigenetic alternations occur during cervical tumorigenesis. Among those changes, aberrant promoter methylation of tumor-suppressor genes gives rise to its silencing functions and results in the significant carcinogenesis of cervical cancer.

\footnotetext{
*Correspondence: tiyuan_li@163.com

+ Contributed equally

'The Second Medical College, Jinan University, Shenzhen Clinical Medical Research Center, Shenzhen People's Hospital, 518020, Shenzhen, PR China Full list of author information is available at the end of the article
}

Currently, the known repressor genes are related to cervical cancer including CCNA1, CHFR, FHIT, PAX1, PTEN, SFRP4, TSLC1 and etc [1]. All these genes mentioned above have performed a wide variety of functions to regulate the transcription and expression, any of which down-regulation as well as promoter hypermethylation will lead to the precursor lesions in cervical development and malignant transformation. DNA methylation is catalyzed by several DNA methyltransferases, including DNMT1, DNMT3a, DNMT3b and etc. DNMT1 is responsible for precise duplicating and maintaining the pre-existing DNA methylation patterns after replication. As reported by Szyf [2], DNMT1 inhibited the transcription of tumor suppressor genes and facilitated the formation of tumorigenesis, which linked to the development of cervical cancer.

\section{Biomed Central}


Meanwhile, Inhibition of DNMT1 activity could reduce hypermethylation of repressive genes and promote its reexpression, and reverse phenotype of malignant tumor. Thus, specific inhibition of DNMT1 could be one strategy for cervical therapy.

In our study, we detected the demethylation and reexpression levels of seven cervical cancer suppressor genes with DNMT1 silencing in Hela and Siha cells. The aim was to elucidate the relations between DNMT1 and abnormal methylation of these genes' promoter as well as the malignant phenotype of tumor cells, which might contribute to the investigations of functions and regulation roles of DNMT1 in cervical cancer.

\section{Materials and methods}

\section{Cell culture and transfection}

The Hela and Siha human cervical cancer cells lines were obtained from American Type Culture Collection (Manassas, VA, USA). Lipofectamine TM2000 was purchased from Invitrogen Co. These cells grown in Dulbeco's Modified Eagle Medium (DMEM) supplemented with 10\% fetal bovine serum and incubated at $37^{\circ} \mathrm{C}$ in a humidified chamber with $5 \% \mathrm{CO}_{2}$. The siRNA primer sequences for DNMT1 were 5'-UUAUGUUGCUCACAAACUUCUUGUC-3' (forward) and 5'-GACAAGAAG UUUGUGAGCAACAUAA-3' (reverse), which were custom synthesized by Shanghai Sangon (Shanghai, China). After transfection, the inhibition efficiency was examined using quantitative polymerase chain reaction (qPCR). Transfections were performed with Lipfectamine TM2000 according to the protocol (Invitrogen Co.).

\section{Real-time qPCR assay}

QPCR was used to analyze mRNA expression level of DNMT1. Total RNA was extracted using Trizol reagent and reversely transcribed into $\mathrm{cDNA}$. The primers for DNMT1 were 5'-AACCTTCACCTAGCCCCAG-3' (forward) and 5'-CTCATCCGATTTGGCTCTTCA3'(reverse); for GAPDH were 5'-CAGCCTCAAGATCATCAGCA-3'(forward) and 5'-TGTGGTCATGAGTCC TTCCA-3' (reverse). QPCR was performed in a $20 \mu \mathrm{l}$ volume containing $1 \mu \mathrm{l}$ cDNA template, $10 \mu \mathrm{l}$ SYBR Green Real-time PCR Master Mix and $1 \mu \mathrm{l}$ of each primer. Levels of seven tumor suppressor genes mRNA expression were also assayed with qPCR. This cycle was defined at $95^{\circ} \mathrm{C}$ for $5 \mathrm{~min}$, followed by 35 cycles of denaturing at $95^{\circ} \mathrm{C}$ for $45 \mathrm{~s}$, annealing at $59^{\circ} \mathrm{C}$ for $35 \mathrm{~s}$ and extension at $72^{\circ} \mathrm{C}$ for $1 \mathrm{~min}$, and followed by the final extension at $72^{\circ} \mathrm{C}$ for $10 \mathrm{~min}$. The primers were shown in Table 1 and Table 2.

\section{Western blot analysis}

Cells were harvested and rinsed twice in ice-cold PBS, and kept on ice for $30 \mathrm{~min}$ in cell lysis buffer containing $1 \mathrm{mM}$ PMSF while agitating constantly, and insoluble cell debris was discarded by centrifugation for $10 \mathrm{~min}$ at $12,000 \mathrm{rpm}$ at $4^{\circ} \mathrm{C}$. The protein samples were separated with $12 \%$ SDS-PAGE and subsequently transferred to PVDF membranes (Millipore). Membranes were blocked with $5 \%$ nonfat dry milk solution either at room temperature for $2 \mathrm{~h}$, and incubated with Rabbit antiDNMT1 and secondary antibody at $37^{\circ} \mathrm{C}$ for $2 \mathrm{~h}$ respectively. The Membranes were stained with an enhanced chemiluminescence solution. Band intensities are normalized to $\beta$-actin as a loading control.

\section{Annexin V-FITC/PI staining and flow cytometry}

Cell cycle analysis: Cells were digested by typsin $(0.25 \%)$ and fixed with cold $70 \%$ ethanol at $48 \mathrm{~h}$ after transfection. After washed in phosphate-buffered saline, samples were incubated with $100 \mu \mathrm{l}$ RNase A at $37^{\circ} \mathrm{C}$ for $30 \mathrm{~min}$ and stained with $400 \mu$ propidium iodide (Sigma). Flow

Table 1 Primers used in RNA expression

\begin{tabular}{|c|c|c|c|c|}
\hline gene & & Sequences & $\operatorname{Tm}\left({ }^{\circ} \mathrm{C}\right)$ & Product Size(bp) \\
\hline \multirow[t]{8}{*}{ QPCR } & GAPDH & $\begin{array}{l}\text { F:5'GGGAAACTGTGGCGTGAT3' } \\
\text { R:5'GAGTGGGTGTCGCTGTTGA3' }\end{array}$ & 59 & 299 \\
\hline & FHIT & $\begin{array}{l}\text { F:5'GGAGATCAGAGGAGGAAATGG3' } \\
\text { R:5'GGGAGTTGGAGTGACCGAG3' }\end{array}$ & 59 & 233 \\
\hline & PTEN & $\begin{array}{l}\text { F:5'ACACGACGGGAAGACAAGTT3' } \\
\text { R:5'CTGGTCCTGGTATGAAGAATG3' }\end{array}$ & 59 & 157 \\
\hline & CHFR & $\begin{array}{l}\text { F:5'GCGTAGAAATGCCCAAACC3' } \\
\text { R:5'TCCATCCAGCCCGAGTAGC3' }\end{array}$ & 59 & 171 \\
\hline & SFRP4 & $\begin{array}{l}\text { F:5'GGCCTCTTGATGTTGACTGTAA3' } \\
\text { R:5'GAGGGATGGGTGATGAGGA3' }\end{array}$ & 59 & 204 \\
\hline & PAX1 & $\begin{array}{l}\text { F:5'GGTAGGAGTAGGGAGCACAGG3' } \\
\text { R:5'CAAGTGTTGCGAGTGGAGG3' }\end{array}$ & 59 & 100 \\
\hline & TSLC1 & $\begin{array}{l}\text { F:5'TATTTCAGGGACTTCAGGC3' } \\
\text { R:5'TCCACCGCAGTGTCTTC3' }\end{array}$ & 59 & 223 \\
\hline & CCNA1 & $\begin{array}{l}\text { F:5'GCCTGGCAAACTATACTGTGAAC3' } \\
\text { R:5'GTGCAGAAGCCTATGACGATTA3' }\end{array}$ & 59 & 295 \\
\hline
\end{tabular}


Table 2 Primers used in MeDIP-qPCR assay

\begin{tabular}{|c|c|c|c|c|}
\hline \multicolumn{2}{|l|}{ gene } & Sequences & \multirow{2}{*}{$\begin{array}{l}\operatorname{Tm}\left({ }^{\circ} \mathrm{C}\right) \\
59\end{array}$} & \multirow{2}{*}{$\begin{array}{l}\text { Product Size(bp) } \\
121\end{array}$} \\
\hline$\overline{M S P}$ & FHIT & $\begin{array}{c}\text { F:5'GAAAGCCATAGTGACAGTAACCC } 3^{\prime} \\
\text { R:5'AAAGCCAAAGATTGTGCGATT3' }\end{array}$ & & \\
\hline & CCNA1 & $\begin{array}{l}\text { F:5'CTCCCGAGCCAGGGTTCT3' } \\
\text { R:5'CGTTCTCCCAACAGCCGC3' }\end{array}$ & 59 & 76 \\
\hline & PTEN & $\begin{array}{l}\text { F:5'GAGCGAATGCAGTCCACG3' } \\
\text { R:5'AGGCAGGGTAGGCTGTTGT3' }\end{array}$ & 59 & 232 \\
\hline & CHFR & $\begin{array}{c}\text { F:5'TTGCCTCAGTATCTCACTTCTT3' } \\
\text { R:5'TCGCCGTCTITACTCCTCT3' }\end{array}$ & 59 & 118 \\
\hline & SFRP4 & $\begin{array}{l}\text { F:5'CCCCATTCTITCCCACCTC3' } \\
\text { R:5'TCGCCTGAAGCCATCGTC3' }\end{array}$ & 59 & 164 \\
\hline & PAX1 & $\begin{array}{c}\text { F:5'AGGAGACCCTGGCATCTTTG3' } \\
\text { R:5'GACGGCGGCTGCTTACTT3' }\end{array}$ & 59 & 168 \\
\hline & TSLC1 & $\begin{array}{l}\text { F:5'GGGAGAACGGCGAGTTTAG3' } \\
\text { R:5'GGCTGAGGGCATCTGTGAG3' }\end{array}$ & 59 & 215 \\
\hline
\end{tabular}

cytometric analysis was performed at $488 \mathrm{~nm}$ to determine the DNA contents.

Apoptosis analysis: Cells were harvested as described above. After adding of $10 \mu \mathrm{l}$ Binding reagent and $1.25 \mu \mathrm{l}$ Annexin V-FITC, samples were suspended in $0.5 \mathrm{ml}$ cold $1 \times$ Binding Buffer and stained with $10 \mu \mathrm{l} \mathrm{PI}$. The samples were then analyzed for apoptosis by flow cytometry.

\section{MTT assay}

Cellular proliferation was measured using MTT assay. $10^{4}$ cells were seeded in 96-well plates and cultured with siRNA-DNMT1 at $37^{\circ} \mathrm{C}$ in a humid chamber with $5 \%$ $\mathrm{CO}_{2}$ for 24 h. $50 \mu \mathrm{l} 1 \times \mathrm{MTT}$ was then added to each well and incubated with cells at $37^{\circ} \mathrm{C}$ for $4 \mathrm{~h}$. After removal of supernatant, $150 \mu \mathrm{l}$ DMSO were added to each well. The optical density (OD) was measured at $550 \mathrm{~nm}$. The percentage of viability was calculated according to the following formula: viability $\%=\mathrm{T} / \mathrm{C} \times 100 \%$, where $\mathrm{T}$ and $\mathrm{C}$ refer to the absorbance of transfection group and cell control, respectively.

\section{MeDIP-qPCR assay}

Transfections were performed as described above. MeDIP assay combined with qPCR were used to quantitatively assess the status of demethylation. Hela and Siha cells were transfected with siRNA and treated with $1.0 \mu \mathrm{M} 5$ az-dC (Sigma) respectively, and harvested at $72 \mathrm{~h}$ after incubation. Genomic DNA was extracted and randomly sheared to an average length of $0.2-1.0 \mathrm{~kb}$ by sonication. Dilution buffer and $60 \mu$ l Protein G Magnetic Bead suspension were added into the fragmented DNA and allowed for more than $10 \mathrm{~min}$ of incubation. DNA was then incubated overnight at $4^{\circ} \mathrm{C}$ with $8 \mu \mathrm{g}$ antibody (Epigentek) against 5 -methylcytosine, followed by $2 \mathrm{~h}$ incubation with Mouse-IgG magnetic beads at $4^{\circ} \mathrm{C}$. The methylated DNA/antibody complexes were then washed with $1 \mathrm{ml}$ cold WB1, WB2 and WB3 buffer. Purified DNA was analyzed by qPCR on an Applied Biosystems 7500 Real-Time PCR System. Real-time PCR was performed in a total $8 \mu \mathrm{l}$ volume containing $1 \mu \mathrm{l}$ of DNA template, $5 \mu \mathrm{l}$

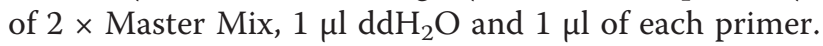
The relative changes in the extent of promoter methylation were determined by measuring the amount of promoter in immunoprecipitated DNA after normalization to the input DNA: \%(MeDNA-IP/Input $)=2^{\wedge}[(\mathrm{Ct}$ (input $)-\mathrm{Ct}$ $($ MeDNA-IP $) \times 100$.

\section{Statistic analysis}

Statistical analyses were performed with SPSS version 13.0(SPSS, Chicago, USA). Quantitative results were given as mean \pm SD and statistical analysis was carried out by t-test. $P$ values less than 0.05 were considered as statistically significant.

\section{Results}

Effects of siRNA on DNMT1 mRNA and protein level

QPCR and western blot were performed to analyze the mRNA and protein expression levels of DNMT1 in Hela and Siha cells at $72 \mathrm{~h}$ after transfection. As shown in Figure 1A, Hela and Siha cells transfected with DNMT1siRNA (transfection group) displayed lower level of mRNA expression $(P<0.01)$, with inhibitory ratios of $56.21 \%$ and $41.31 \%$ respectively compared with control group (negative siRNA). No significant change in DNMT1 mRNA expression was found between control group and blank control (Lipo 2000). The transcript quantity of GAPDH in transfection group, control group and blank control did not change significantly. Figure $1 \mathrm{~B}$ showed the DNMT1 protein expression levels in Hela and Siha cells at $72 \mathrm{~h}$ after transfected with DNMT1-siRNA. The protein level of DNMT1 decreased significantly compared with control group and blank control $(P<0.01)$. The inhibitory ratios of DNMT1 protein level in Hela and Siha cells were $50.31 \%$ and $99.76 \%$, respectively. 


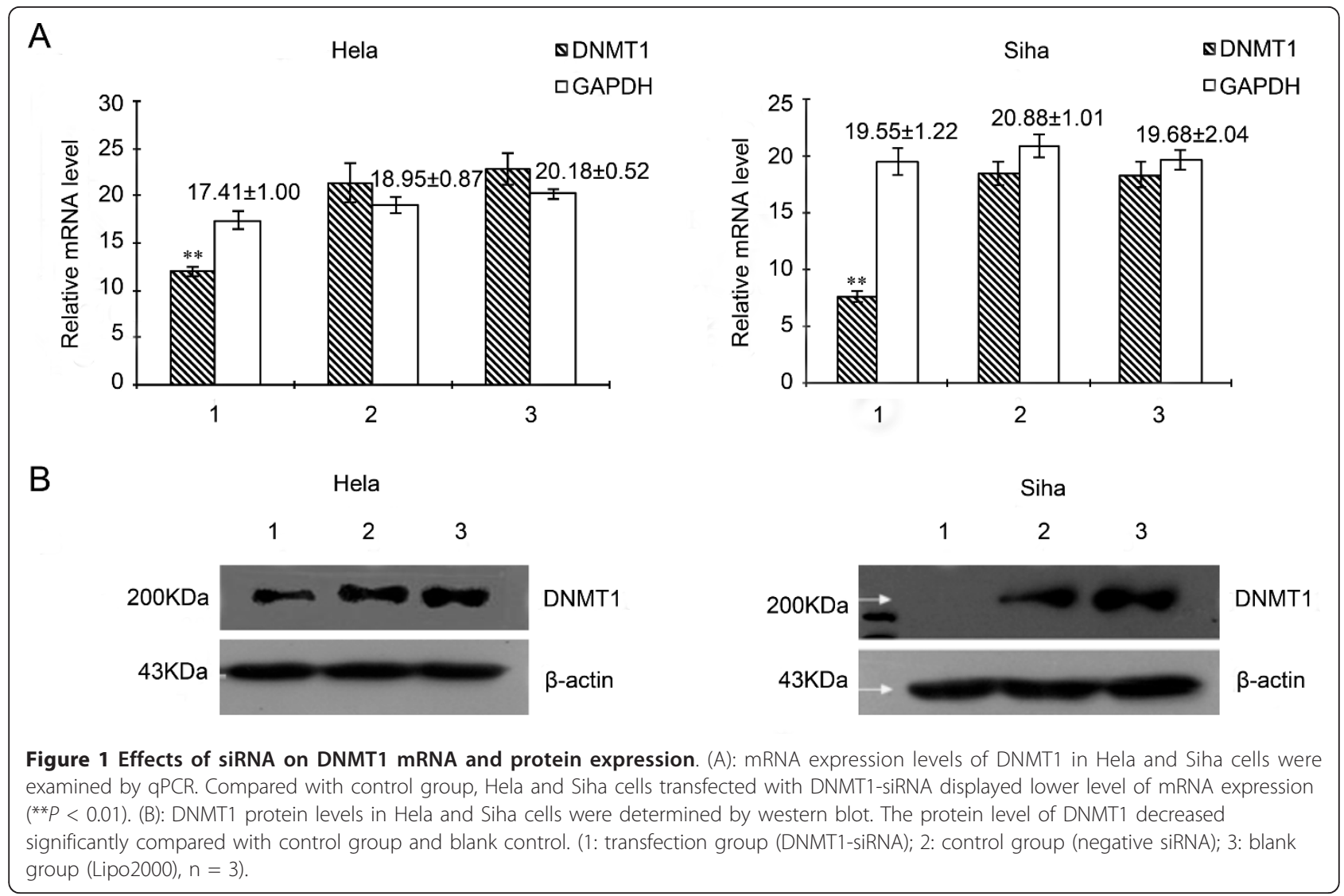

Effects of DNMT1 silencing on cell cycle and apoptosis The G0/G1 ratio $(74.72 \pm 3.17 \%)$ of Hela cells in transfection group was higher than that in control group $(65.88 \pm 3.23 \%)(P<0.01)$, and cells at $\mathrm{S}$ phase were fewer compared with control group. Meanwhile, The G0/G1 ratio $(76.43 \pm 2.20 \%)$ of Siha cells in transfection group displayed significantly higher compared with control group $(66.4 \pm 1.99 \%)(P<0.01)$, while cells at $\mathrm{S}$ phase were fewer than those in control group. No significant changes in G0/G1 ratio or cells at $\mathrm{S}$ phase were detected between the control group and blank control (Figure 2A). Furthermore, as shown in Figure 2B, the apoptosis of Hela cells in transfection group was significantly higher than that in control group $(P<0.01)$. Similar results were observed in Siha cells.

\section{Effects of DNMT1 silencing on cell growth and proliferation}

Cell growth and proliferation of Hela and Siha cells were examined using MTT assay. As shown in Figure 3, viabilities of Hela cells in transfection group were $91.47 \%$, $86.74 \%, 78.92 \%$ and $48.98 \%$ at $24,48,72$ and 96 h, respectively $(P<0.05)$ compared with control group at each time point. We observed the similar results in Siha cells with viabilities of $90.45 \%, 84.16 \%, 71.09 \%$ and $60.47 \%$ at 24,48 ,
72 and $96 \mathrm{~h}$ after transfection, respectively $(P<0.05)$ compared with control group at each time point.

\section{Effects of DNMT1 silencing on gene demethylation and mRNA expression level in Hela cell}

Methylation status and mRNA expression level of seven repressive genes in Hela cells were performed with MeDIP-qPCR assay and Real-time PCR (Figure 4) compared with drug group(5-aza-dC, methylase inhibitors), control group and blank group. Specifically, PAX1, SFRP4 and TSLC1 possessed higher levels of methylation, while CHFR and FHIT were relatively lower. Except for FHIT and PTEN, the rest five suppressor genes CCNA1, CHFR, PAX1, SFRP4 and TSLC1 in transfection group displayed lower level of methylation status compared with control group $(P<0.01)$, which decreased to $34.42 \%, 15.57 \%, 22.36 \%, 52.09 \%$ and $35.53 \%$, respectively. The effects of DNMT1-siRNA and 5 -aza-dC treatment were performed the identical phenomenon. The relative mRNA levels of seven repressive genes were detected by Real-time PCR. It's clear that the expression of PTEN was higher than other genes. Except for FHIT and PTEN, the expression levels of CCNA1, CHFR, PAX1, SFRP4 and TSLC1 in transfection group were higher than those in control group, 

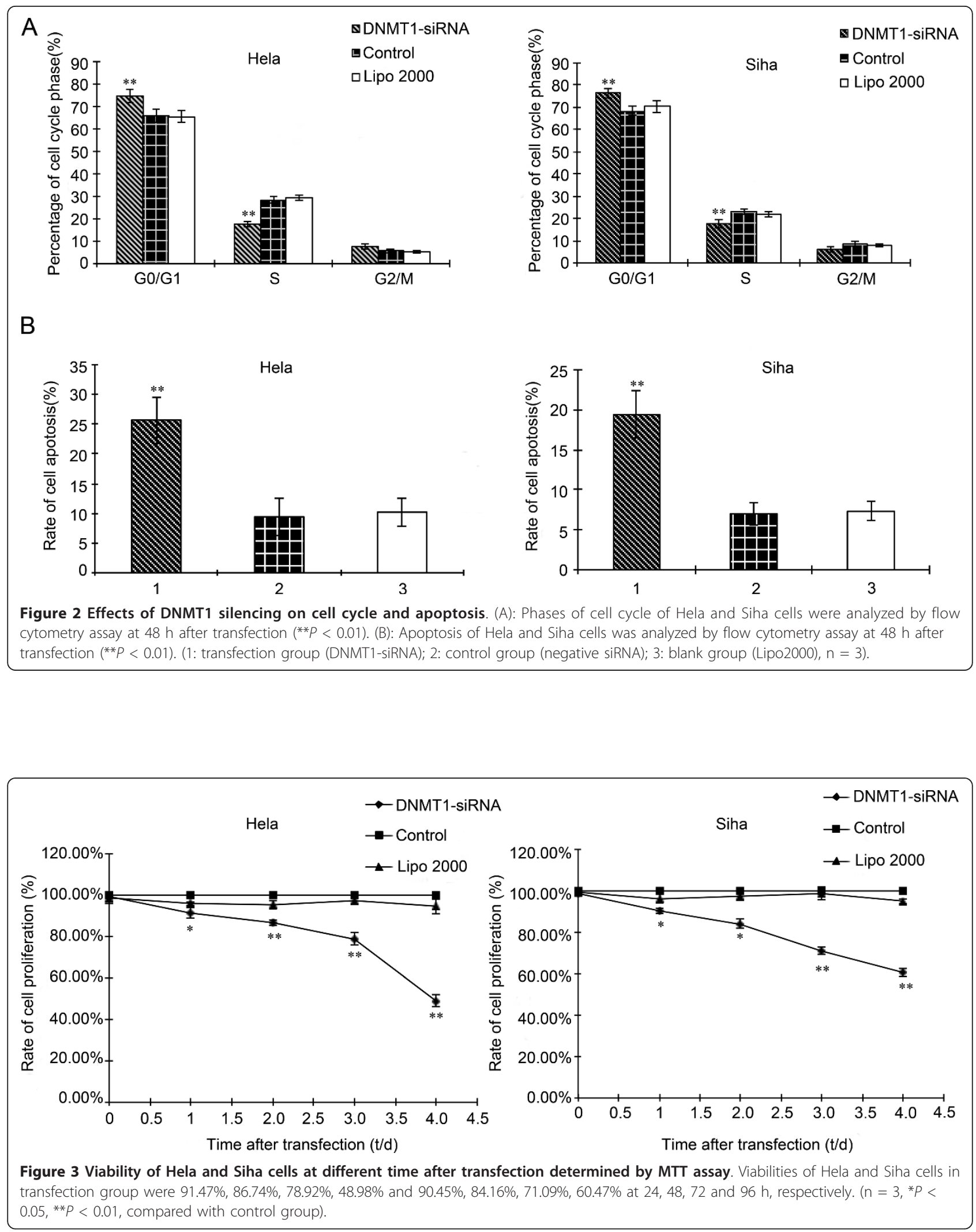


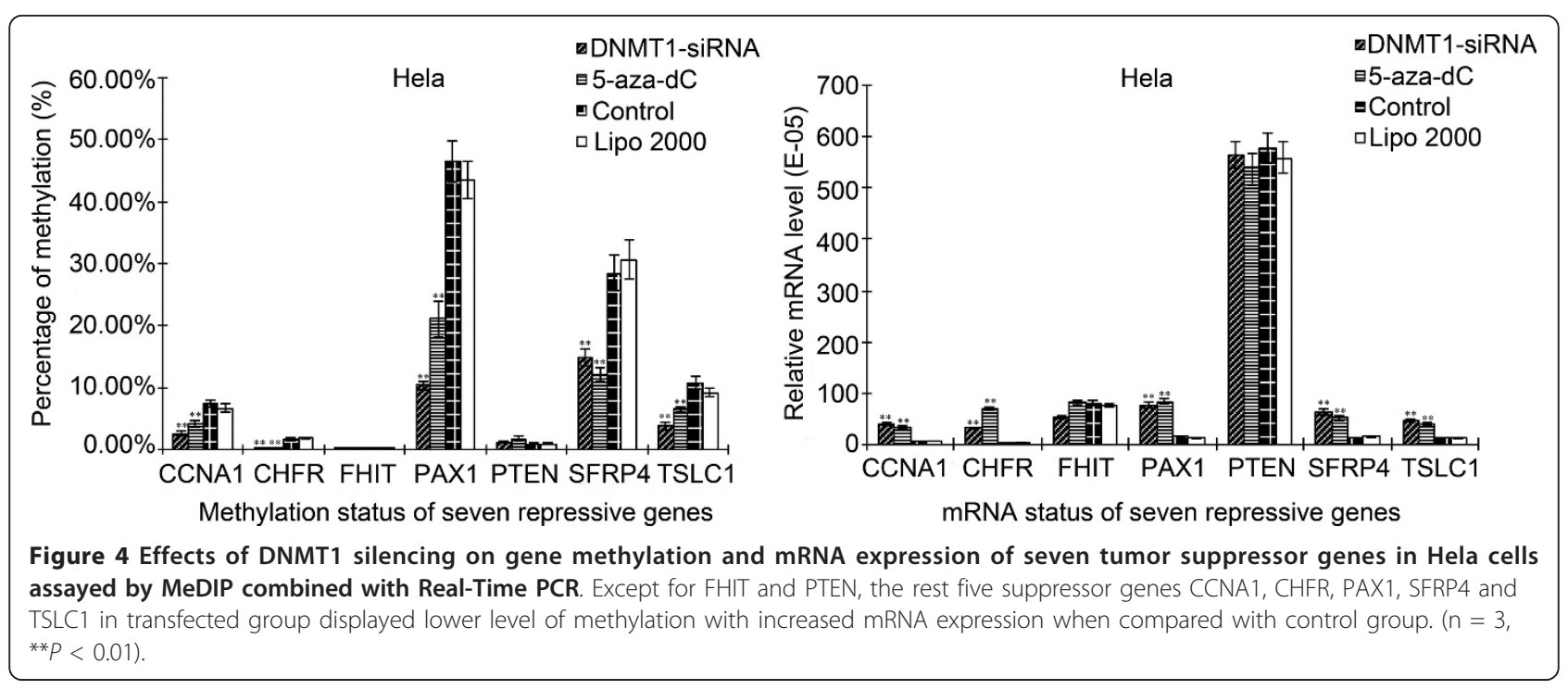

with relative mRNA levels increased 6.13, 10.39, 4.98, 4.87 and 3.51 folds, respectively.

Effects of DNMT1 silencing on gene demethylation and mRNA expression level in Siha cell

Figure 5 showed the methylation status and mRNA levels in Siha cells were similar to those in Hell cells. PAX1, SFRP4 and TSLC1 possessed higher level of methylation status, while PTEN and FHIT were relatively lower. Except for FHIT and CHFR, the rest five repressor genes CCNA1, PAX1, PTEN, SFRP4 and TSLC1 in transfection group displayed lower level of methylation compared with control group $(P<0.01)$, which decreased to $35.21 \%$, $23.75 \%, 19.51 \%, 33.15 \%$ and $38.04 \%$, respectively. Furthermore, the relative mRNA expression level of PTEN was higher than other genes. Except for FHIT and CHFR, the mRNA expression levels of CCNA1, PAX1,
PTEN, SFRP4 and TSLC1 in transfection group were higher than those in control group, with relative mRNA levels increased $7.22,2.88,2.32,7.04$ and 3.47 folds, respectively.

\section{Discussion}

DNMT1 silencing in cervical cancer cells could induce re-expression of most tumor suppressor genes by demethylating its promoter region, and co-silencing of DNMT1 and DNMT3b might perform a greater inhibitory effect on tumorigenesis [3]. Sowinska [4] demonstrated that combined DNMT1 and DNMT3b siRNAs could enhance promoter demethylation and re-expression of CXCL12 in MCF-7 breast cancer as well as AsPC1 in pancreatic carcinoma cell lines, and suggested that they acted synergistically in inhibiting CpG island hypermethylation of tumor suppressor genes. Rhee et al

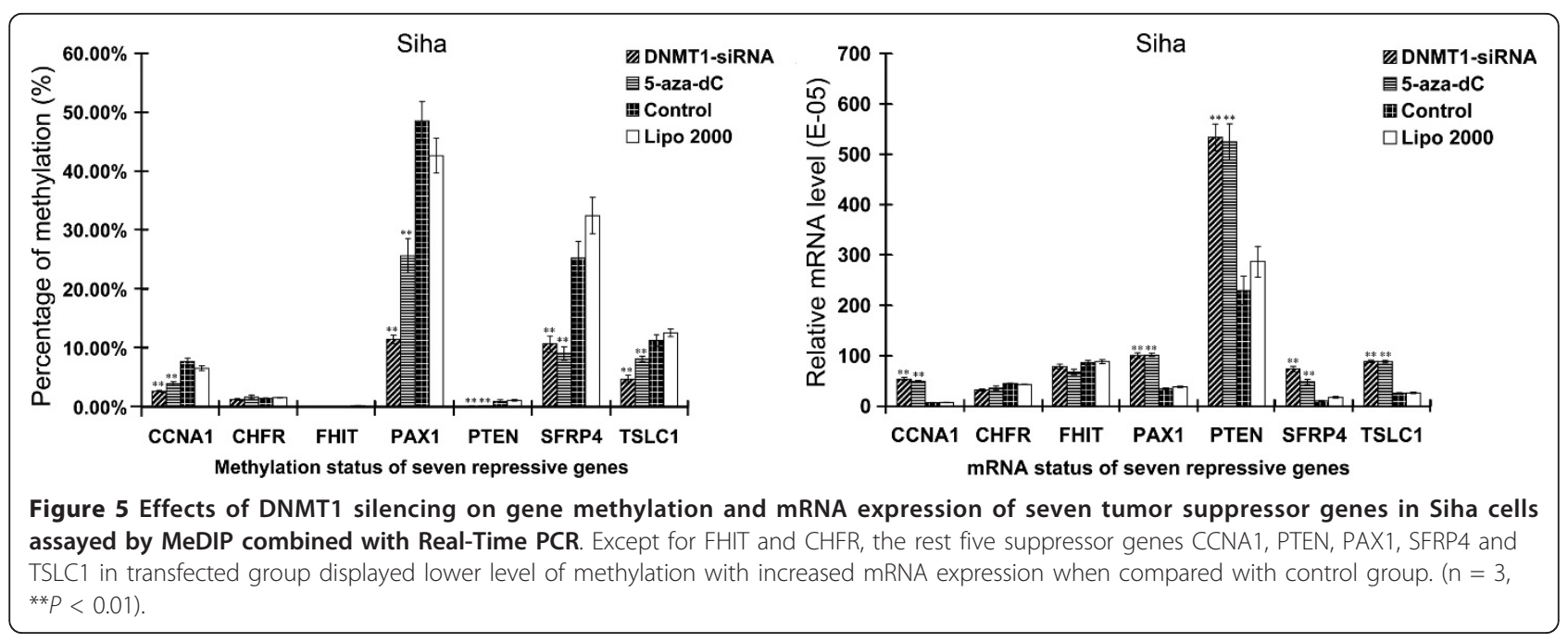


[5] reported that DNMT3b deletion in a colorectal cancer cell line reduced global DNA methylation by less than 3\%, but co-silencing of both DNMT1 and DNMT3b nearly eliminated methyltransferase activity, and reduced genomic DNA methylation by greater than $95 \%$. Thus, DNMT1 and DNMT3b play the significant role in promoter methylation of tumor suppressor genes and tumorigenesis in its early status. Currently, functions and mechanisms of DNMTs in cervical cancer cells remained unclear, and whether DNMT1 and DNMT3b act synergistically or through other ways exploration efforts were still required study.

In human bladder cancer cells, selective depletion of DNMT1 with siRNA induced demethylation and reactivation of the silenced tumor-suppressor gene CDKN2A [6]. RNAi-mediated knockdown of DNMT1 resulted in significant reduction of promoter methylation and re-expression of RASSF1A, p16, and HPP1 in HCC1954 breast cancer cells [7]. In ovarian cancer cell line CP70, DNMT1 siRNA treatment led to a partial removal of DNA methylation from three inactive promoter CpG islands, TWIST, RASSF1A, and HIN-1, and restored the expression of these genes [8]. Thus, RNAi-mediated DNMT1 depletion in different tumor cells could induce demethylation of various tumor suppressor genes and enhance re-expression. However, contradictory results were reported even in the same cell line. Ting et al [9] found that hypermethylation of CDKN2A, SFPR1, GATA4 and GATA5 were still maintained in HCT116 colorectal cancer cells after transiently or stably depleted of DNMT1, and suggested that DNMT1 might not play the dominant effect which caused hypermethylation of $\mathrm{CpG}$ islands in tumor suppressor genes. Knockout of DNMT1 in HCT116 cells by homologous recombination only reduced global DNA methylation by $20 \%$ and p 16 maintained completely methylated status. Besides, methylations of HMLH1, p16 and CDH1 in gastric-cancer tissue samples at different progress periods do not correlate with the expression of DNMT1 directly [10]. Therefore, whether over-expression of DNMT1 accounts for the only or key causes of hypermethylation of tumor suppressor genes remains to be confirmed.

Currently, correlation between methlylation and mRNA expression still remains unclear. In our study, methylation status of five suppressor genes (such as PAX1) in transfection group was significantly lower than that in control group or blank control, and the mRNA expression levels were higher as compared to the two types of control, suggesting that lower level of methylation facilitates mRNA expression. This trend was confirmed when CCNA1, SFRP4, TSLC1 and CHFR in Hela cells and CCNA1, PTEN, SFRP4 and TSLC1 in Siha cells were analyzed.

Surprisingly, transfection did not affect the methylation status and mRNA expression of FHIT and PTEN in
Hela cells and FHIT and CHFR in Siha cells in our study, even though both of these two genes might achieve high mRNA expression through low methylation. It was previously reported that there was no PTEN mutation in 63 cases of squamous cervical carcinomas, but $58 \%$ of the cases showed high methylation of PTEN promoter [11,12]. Wu et al [13] reported that FHIT was highly methylated in Hela, C33A and Siha cervical cancer cells, and that aberrant methylation of the FHIT gene might be a key mechanism for cervical tumorigenesis, which could be reactivated and whose tumor suppressing function could be restored by treatment of demethylating agent. Banno et al [14] reported that cervical smears showed aberrant methylation of CHFR in $12.3 \%$ of adenocarcinoma specimens, while aberrant DNA methylation was not detected in normal cervical cells. These researches demonstrated us that FHIT and PTEN in Hela cells and FHIT and CHFR in Siha cells might have the other regulation pathways for carcinogenesis or transcription control, and which needs more tests of cervical cancer cells and clinical specimens.

Apart from DNMT1 silencing, we treated Hela and Siha cells with 5 -aza-dC, which revealed the similar results with transfection group. Five repressor genes were demethylated to various degrees and the mRNA expressions were also increased. These results are in accordance with the findings of other reports [15-19], which could be important in the development of new and effective strategy in cervical treatment.

\section{Conclusions}

In conclusion, our study demonstrates that DNMT1 silencing could suppress proliferation and induce apoptosis of Hela and Siha cells. DNMT1-siRNA induces demethylation of five tumor suppressor genes, including CCNA1, CHFR, PAX1, SFRP4 and TSLC1 in Hela cells and CCNA1, PTEN, PAX1, SFRP4 and TSLC1 in Siha cells, and enhances their mRNA expression. In a word, DNMT1 represents an important potential diagnostic and therapeutic target for cervical cancer.

\section{Acknowledgements}

This study was supported by the Shenzhen major research projects of healthy department.

\section{Author details}

${ }^{1} T$ The Second Medical College, Jinan University, Shenzhen Clinical Medical Research Center, Shenzhen People's Hospital, 518020, Shenzhen, PR China. ${ }^{2}$ The Pharmacy College, Jinan University, 510632, Guangzhou, PR China.

\section{Authors' contributions}

YZ carried out the molecular genetic studies and wrote the manuscript, FQC and RC analyzed the dates and informations. YHS gave assistance with technical performance, SYZ contributed to the writing of the manuscript, TYL designed the study and revised the manuscript. All authors read and approved the final manuscript. 


\section{Competing interests}

The authors declare that they have no competing interests.

Received: 17 July 2011 Accepted: 17 October 2011

Published: 17 October 2011

\section{References}

1. Ongenaert M, Wisman GB, Volders HH, Koning AJ, Zee AG, van Criekinge W, Schuuring E: Discovery of DNA methylation markers in cervical cancer using relaxation ranking. BMC Med Genomics 2008, 1:57.

2. Szyf M: The role of DNA methyltransferase 1 in growth control. Front Biosci 2001, 6:D599-609.

3. Peng DF, Kanai Y, Sawada M, Ushijima S, Hiraoka N, Kitazawa S, Hirohashi S: DNA methylation of multiple tumor-related genes in association with overexpression of DNA methyltransferase 1 (DNMT1) during multistage carcinogenesis of the pancreas. Carcinogenesis 2006, 27(6):1160-1168.

4. Sowinska A, Jagodzinski PP: RNA interference-mediated knockdown of DNMT1 and DNMT3B induces CXCL12 expression in MCF-7 breast cancer and AsPC1 pancreatic carcinoma cell lines. Cancer letters 2007, 255(1):153-159.

5. Rhee I, Bachman KE, Park BH, Jair KW, Yen RW, Schuebel KE, Cui H, Feinberg AP, Lengauer C, Kinzler KW, et al: DNMT1 and DNMT3b cooperate to silence genes in human cancer cells. Nature 2002, 416(6880):552-556

6. Robert SM, Beaulieu Normand, Gauthier France: DNMT1 is required to maintain $\mathrm{CpG}$ methylation and aberrant gene silencing in human cancer cells. Nature genetics 2002, 33(9):61-65.

7. Suzuki M, Sunaga N, Shames DS, Toyooka S, Gazdar AF, Minna JD: RNA interference-mediated knockdown of DNA methyltransferase 1 leads to promoter demethylation and gene re-expression in human lung and breast cancer cells. Cancer research 2004, 64(9):3137-3143.

8. Leu YW, Rahmatpanah F, Shi H, Wei SH, Liu JC, Yan PS, Huang TH: Double RNA interference of DNMT3b and DNMT1 enhances DNA demethylation and gene reactivation. Cancer research 2003, 63(19):6110-6115.

9. Ting AH, Jair KW, Suzuki H, Yen RW, Baylin SB, Schuebel KE: CpG island hypermethylation is maintained in human colorectal cancer cells after RNAi-mediated depletion of DNMT1. Nature genetics 2004, 36(6):582-584

10. Ye C, Shrubsole MJ, Cai Q, Ness R, Grady WM, Smalley W, Cai H, Washington $\mathrm{K}$, Zheng W: Promoter methylation status of the MGMT, hMLH1, and CDKN2A/p16 genes in non-neoplastic mucosa of patients with and without colorectal adenomas. Oncology reports 2006, 16(2):429-435.

11. Hsieh SM, Maguire DJ, Lintell NA, McCabe M, Griffiths LR: PTEN and NDUFB8 aberrations in cervical cancer tissue. Advances in experimental medicine and biology 2007, 599:31-36.

12. Qi M, Anderson AE, Chen DZ, Sun S, Auborn KJ: Indole-3-carbinol prevents PTEN loss in cervical cancer in vivo. In Molecular medicine. Volume 11. Cambridge, Mass; 2005:(1-12):59-63.

13. Wu Y, Meng L, Wang H, Xu Q, Wang S, Wu S, Xi L, Zhao Y, Zhou J, Xu G, et al: Regulation of DNA methylation on the expression of the FHIT gene contributes to cervical carcinoma cell tumorigenesis. Oncology reports 2006, 16(3):625-629.

14. Banno K, Yanokura M, Kawaguchi M, Kuwabara Y, Akiyoshi J, Kobayashi Y, Iwata T, Hirasawa A, Fujii T, Susumu N, et al: Epigenetic inactivation of the CHFR gene in cervical cancer contributes to sensitivity to taxanes. International journal of oncology 2007, 31(4):713-720.

15. Cheung HW, Ching YP, Nicholls JM, Ling MT, Wong YC, Hui N, Cheung A, Tsao SW, Wang Q, Yeun PW, et al: Epigenetic inactivation of CHFR in nasopharyngeal carcinoma through promoter methylation. Molecular carcinogenesis 2005, 43(4):237-245.

16. Chung MT, Sytwu HK, Yan MD, Shih YL, Chang CC, Yu MH, Chu TY, Lai HC, Lin YW: Promoter methylation of SFRPs gene family in cervical cancer. Gynecologic oncology 2009, 112(2):301-306.

17. Kitkumthorn N, Yanatatsanajit $\mathrm{P}$, Kiatpongsan S, Phokaew C, Triratanachat S, Trivijitsilp P, Termrungruanglert W, Tresukosol D, Niruthisard S, Mutirangura A: Cyclin A1 promoter hypermethylation in human papillomavirus-associated cervical cancer. BMC cancer 2006, 6:55.

18. Lai HC, Lin YW, Huang TH, Yan P, Huang RL, Wang HC, Liu J, Chan MW, Chu TY, Sun CA, et al: Identification of novel DNA methylation markers in cervical cancer. International journal of cancer 2008, 123(1):161-167.
19. Steenbergen RD, Kramer D, Braakhuis BJ, Stern PL, Verheijen RH, Meijer CJ, Snijders PJ: TSLC1 gene silencing in cervical cancer cell lines and cervical neoplasia. Journal of the National Cancer Institute 2004, 96(4):294-305.

doi:10.1186/1756-9966-30-98

Cite this article as: Zhang et al:: Effects of DNMT1 silencing on malignant phenotype and methylated gene expression in cervical cancer cells. Journal of Experimental \& Clinical Cancer Research 2011 30:98.

\section{Submit your next manuscript to BioMed Central and take full advantage of:}

- Convenient online submission

- Thorough peer review

- No space constraints or color figure charges

- Immediate publication on acceptance

- Inclusion in PubMed, CAS, Scopus and Google Scholar

- Research which is freely available for redistribution

Submit your manuscript at www.biomedcentral.com/submit
Biomed Central 